\title{
Does ICT Participate in Economic Convergence among Asian Countries: Evidence from Dynamic Panel Data Model
}

\author{
Bilal MEHMOOD ${ }^{1}$, Parvez AZIM ${ }^{2}$ \\ ${ }^{1}$ Department of Economics, Government College University, Lahore, Pakistan \\ ${ }^{2}$ Department of Economics, Government College University, Faisalabad, Pakistan \\ digital.economist@gmail.com,dr_azim@hotmail.com
}

Conventional Convergence models usually oversee the role of information and communications technology (ICT) as a determinant of convergence. This paper introduces ICT as a factor contributing towards economic convergence in Asian countries. In addition to ICT, other factors like demographic traits, level of human development and electricity consumption are used as regressors. System GMM technique is used to estimate convergence regression for selected Asian countries for data of time span 2001-2010. Support for ICT-augmented convergence is found, implying that ICT has the tendency to participate in convergence process. Suitable demographic features, human development and electricity consumption are also found to contribute to economic convergence in the sample countries of Asia. Findings of this paper indicate the need to complement the favorable demographic endowments in Asian economies with economically productive usage of ICT to proceed towards economic convergence in Asian Region.

Keywords: Convergence Models, Information and Communication Technology (ICT), System Generalized Method of Moments (SYS-GMM), Human Development Index (HDI), Electricity Consumption

\section{1}

\section{Introduction}

Importance of information has been pivotal since beginning of human civilization. Since time immemorial the information has been serving as a competitive edge for its possessors [12]. During $20^{\text {th }}$ century, the advent of digital devices has hotfooted the flow of information and ability to process it. This technology is termed as Information and communication technology (ICT). During the last half of $20^{\text {th }}$ century, 'information revolution' was made possible through the 'digital' Information and Communication Technology 'ICT' [12]. The ICT revolution is crucial insofar as it involves technologies geared to the production and dissemination of knowledge and information. These new technologies, that first emerged in the 1950s and then really took off with the advent of the Internet, have breathtaking potential. It is worth noting that the differences between communication technology and information technology have become fuzzy. e.g. mobile phones are principally tools for communication. But with the invention of wireless technology, users can access information via cellular phone. Inter- net is primarily a tool of information technology, yet many Internet users communicate mutually through their personal computers. Economic convergence refers to the process by which relatively poorer regions or countries grow faster than their rich counterparts. The convergence hypothesis is advanced by [22] and is documented by [8] and [5]. This paper includes ICT and in economic convergence and calls it ICT-augmented. For the sake of simplicity, the word 'Economic convergence' is interchangeably used as 'convergence'. As documented in empirical literature, conditional beta convergence is a more realistic exercise because it reflects the convergence of countries after controlling for differences in steady states. Absolute sigma $(\sigma)$ convergence is another form of convergence theory but suffers with lack of empirical evidence. Conditional convergence is simply a confirmation of a result predicted by the neoclassical growth model: those countries with similar steady states exhibit convergence. This does not imply that all countries in the world would converge to the same steady state; rather they would converge to 
their own steady states.

\section{Objective}

This paper inquires the role of ICT in achieving economic convergence among Asian countries. It is expected due to miraculous ability of ICT to process information and hence become economically meaningful. Classic evidence of this ability is Moore's law that purports an exponentially increasing 'information processing' capability in microelectronics, society and economy. Another instance is Gilder Law that asserts bandwidth of network would triple each year for the span of 25 years. Till date this prediction is almost true. Therefore, it is pertinent to discuss the role of ICT in the convergence hypothesis. This paper empirically examines the role of ICT in economic convergence after including demographic features, level of human development and electricity consumption.

\section{Literature Survey}

Convergence regression has been estimated with a variety of explanatory variables. [13] incorporates federal transfers in the conver- gence regression to inquire its role in growth. However results do not imply convergence. In similar veins, [21] attempts to explicate regional output inequality within $13 \mathrm{EU}$ countries, and uses social transfers as an explanatory fiscal variable. Author does find evidence of convergence using the social transfers in reducing output inequality.

The efforts to incorporate ICT as an explanatory variable are rare and a noticeable effort in this regard is in [16]. His exercise of growth empirics on member states of European Union reveals that $R \& D$ expenditure initiated from abroad impacts GDP growth positively and in a statistically significant way. To augment the literature for Asian region, this paper quantitatively assesses the role that ICT play in convergence regressions for the sample countries.

Flowchart gives a scheme of theoretical framework in this paper. There is innovation in [4] is the addition of ICT as a factor contributing to economic convergence. Since ICT is empirically evidenced as an agent of economic growth, it can be tested as a factor that enters positively into convergence regression.

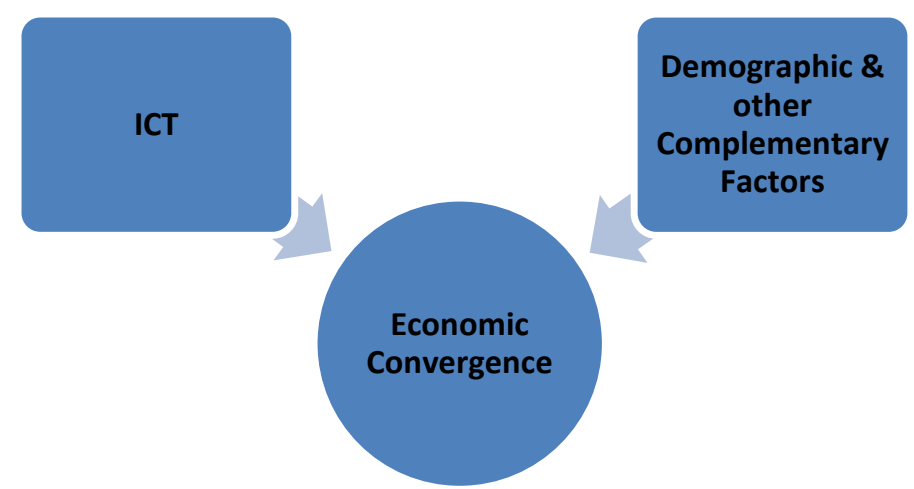

Fig. 1. Converging Radial Diagram for ICT Augmented Convergence Hypothesis Source: Inspired from Barro and Sala-i-Martin (1992)

\section{Estimable Model for ICT Augmented Convergence Hypothesis}

This paper reposes on this literature and elaborates existing findings by using a rigorous methodological approach applied at a regional level panel dataset. Foundation for the analysis is provided in [4] in terms of conditional convergence. In this paper, the growth equation in [4] is augmented with ICT. The use of ICT and knowledge related variable(s) is justified for long run steady state growth due to non-decreasing returns. The trait of knowledge of being non rival and hence passing without diminishing its value allows for non-decreasing returns. This paper examines the role of ICT in determining the conditional convergence across selected Asian 
countries which will be tested by estimating the following model:

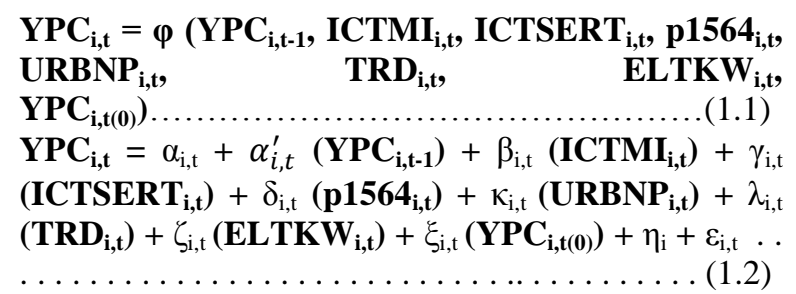

Where, $\mathbf{Y} \mathbf{P} \mathbf{C}_{\mathbf{i}, \mathbf{t}}$ is income per capita estimated as the ratio of national income and $\mathbf{Y} \mathbf{P C}_{\mathbf{i}, \mathrm{t}-1}$ is one year lagged version of income per capita, rendering the model dynamic. ICTMI is Information \& Communication Technology Maturation Index. For the complementary effects between ICT and tertiary level education, ICTSERT as a product of ICT and SERT is included among regressors. SERT 'tertiary school enrolment (\% gross)' as a proxy of human capital is used following [5]. In lieu of 'secondary school enrollment' (SERS), SERT is chosen because ICT users with higher levels of education are economi- cally more productive. [11] also advocate the role of SERT in improving ICT diffusion in an economy and hence likely to be a reinforcing factor for ICT-productivity nexus. It reveals the interaction effects of ICT and school enrolment rate at tertiary level. To include the complementary effects culminating from demographic features, p1564 (population with at between 15 and 64 years) and URBNP (\%age of urban population) are included. Welfare related complementarily is investigated using HDI (Human development index) and ELTKW is the technology related determinant income growth by using the variable 'electric power consumption in $\mathrm{kWh}$ '. $\mathrm{YPC}_{\mathrm{i}, \mathrm{t}(\mathrm{0})}$ is the initial condition of YPC included to test existence of the ICTaugmented conditional convergence. [21] discover 'conditional convergence' to be a robust characteristic of growth regressions, i.e., it holds true for many 'conditioning variables'. Following is the detailed table of data definition and sources:

Table 1. List of Countries, Variables, their Definitions and Data Sources

\begin{tabular}{|c|c|c|c|}
\hline $\begin{array}{l}\text { Sr. } \\
\text { No. }\end{array}$ & $\begin{array}{l}\text { Variable \& its } \\
\text { Notation }\end{array}$ & Definition & Source \\
\hline 1 & $\begin{array}{l}\text { Logarithm of } \\
\text { GDP per capita, } \\
\text { PPP (constant } \\
2005 \text { internation- } \\
\text { al \$) } \\
\text { YPC }_{\mathbf{i}, \mathbf{t})}\end{array}$ & $\begin{array}{l}\text { "GDP per capita based on purchasing power parity (PPP). PPP GDP is } \\
\text { gross domestic product converted to international dollars using pur- } \\
\text { chasing power parity rates. An international dollar has the same pur- } \\
\text { chasing power over GDP as the U.S. dollar has in the United States. } \\
\text { GDP at purchaser's prices is the sum of gross value added by all resi- } \\
\text { dent producers in the economy plus any product taxes and minus any } \\
\text { subsidies not included in the value of the products. It is calculated } \\
\text { without making deductions for depreciation of fabricated assets or for } \\
\text { depletion and degradation of natural resources. Data are in constant } \\
2005 \text { international dollars." }\end{array}$ & WDI 2011 \\
\hline 2 & $\begin{array}{l}\text { Labor force, total } \\
\mathbf{L}_{\mathbf{i}, \mathbf{t}}\end{array}$ & $\begin{array}{l}\text { Total labor force comprises people ages } 15 \text { and older who meet the In- } \\
\text { ternational Labor Organization definition of the economically active } \\
\text { population: all people who supply labor for the production of goods and } \\
\text { services during a specified period. It includes both the employed and } \\
\text { the unemployed. While national practices vary in the treatment of such } \\
\text { groups as the armed forces and seasonal or part-time workers, in gen- } \\
\text { eral the labor force includes the armed forces, the unemployed, and } \\
\text { first-time job-seekers, but excludes homemakers and other unpaid care- } \\
\text { givers and workers in the informal sector. }\end{array}$ & WDI 2011 \\
\hline 3 & $\begin{array}{l}\text { Human Devel- } \\
\text { opment Index } \\
\text { HDI }_{\mathbf{i}, \mathbf{t}}\end{array}$ & 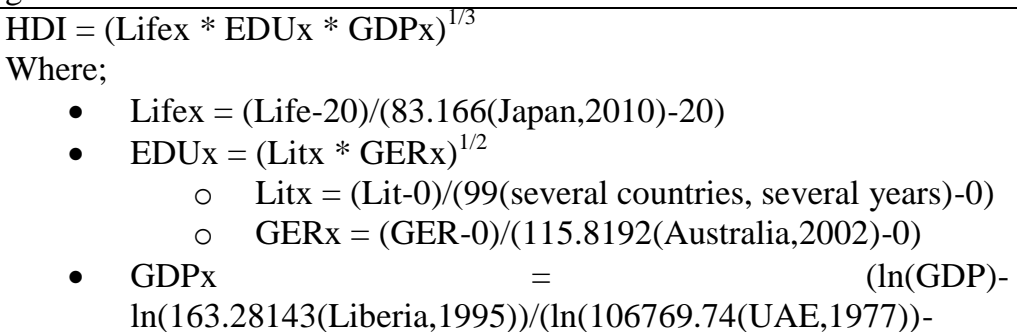 & UNDP \\
\hline
\end{tabular}




\begin{tabular}{|c|c|c|c|}
\hline & & $\ln (163.28143($ Liberia, 1995)). & \\
\hline 4 & $\begin{array}{l}\text { Urban population } \\
\text { URBNP }_{\mathbf{i}, \mathbf{t}}\end{array}$ & $\begin{array}{l}\text { "Urban population refers to people living in urban areas as defined by } \\
\text { national statistical offices. It is calculated using World Bank population } \\
\text { estimates and urban ratios from the United Nations World Urbanization } \\
\text { Prospects." }\end{array}$ & WDI 2011 \\
\hline 5 & $\begin{array}{l}\text { Population ages } \\
15-64(\% \text { of to- } \\
\text { tal) } \\
\text { P1564 }_{i, t}\end{array}$ & $\begin{array}{l}\text { Population ages } 15 \text { to } 64 \text { is the percentage of the total population that is } \\
\text { in the age group } 15 \text { to } 64 \text {. Population is based on the de facto definition } \\
\text { of population. }\end{array}$ & WDI 2011 \\
\hline 6 & $\begin{array}{l}\text { Fixed telephone } \\
\text { lines per } 100 \text { in- } \\
\text { habitants } \\
\text { FTL }_{\mathbf{i}, \mathbf{t}}\end{array}$ & $\begin{array}{l}\text { "It refers to the number of fixed telephone lines in a country for each } \\
100 \text { inhabitants." } \\
\text { Calculation: by dividing the number of fixed telephone lines by the to- } \\
\text { tal population and then multiplying by } 100 \text {. }\end{array}$ & ITU 2011 \\
\hline 7 & $\begin{array}{l}\text { Mobile cellular } \\
\text { telephone sub- } \\
\text { scriptions per } \\
100 \text { inhabitants } \\
\text { MBLC }_{\mathbf{i}, \mathbf{t}}\end{array}$ & $\begin{array}{l}\text { "It refers to the number of mobile cellular telephone subscriptions in a } \\
\text { country for each } 100 \text { inhabitants." } \\
\text { Calculation: by dividing the number of mobile cellular telephone sub- } \\
\text { scriptions by the total population and then multiplying by } 100 \text {. }\end{array}$ & ITU 2011 \\
\hline 8 & $\begin{array}{l}\text { Fixed broadband } \\
\text { Internet sub- } \\
\text { scribers } \\
\text { FBBS }_{\mathbf{i}, \mathrm{t}}\end{array}$ & $\begin{array}{l}\text { "It refers to the number of fixed broadband internet subscribers in a } \\
\text { country for each } 100 \text { inhabitants." } \\
\text { Calculation: by dividing the number of fixed broadband Internet sub- } \\
\text { scribers by the total population and then multiplying by } 100 \text {. }\end{array}$ & ITU 2011 \\
\hline 9 & $\begin{array}{l}\text { Fixed Internet } \\
\text { subscribers per } \\
100 \text { inhabitants } \\
\text { FIS }_{\mathbf{i}, \mathbf{t}}\end{array}$ & $\begin{array}{l}\text { "It refers to the number of fixed internet subscribers in a country for } \\
\text { each } 100 \text { inhabitants." } \\
\text { Calculation: by dividing the number of fixed Internet subscribers by } \\
\text { the total population and then multiplying by } 100 \text {. }\end{array}$ & ITU 2011 \\
\hline 10 & $\begin{array}{l}\text { Internet users per } \\
100 \text { inhabitants } \\
\text { INTU }_{\mathbf{i}, \mathbf{t}}\end{array}$ & $\begin{array}{l}\text { "It refers to the number of internet users in a country for each } 100 \text { in- } \\
\text { habitants." } \\
\text { Calculation: by dividing the number of mobile broadband subscrip- } \\
\text { tions by the total population and then multiplying by } 100 \text {. }\end{array}$ & ITU 2011 \\
\hline 11 & $\begin{array}{l}\text { Information \& } \\
\text { Communication } \\
\text { Technology } \\
\text { Maturation Index } \\
\text { ICTMI }_{\mathbf{i}, \mathbf{t}}\end{array}$ & $\begin{array}{l}=(\text { Fixed telephone lines per } 100 \text { inhabitants })+0.2 * \text { (Mobile cellular } \\
\text { telephone subscriptions per } 100 \text { inhabitants })+0.2 * \text { (Fixed broadband } \\
\text { Internet subscribers })+0.2 * \text { (Fixed Internet subscribers per } 100 \text { inhab- } \\
\text { itants })+0.2 * \text { (Internet users per } 100 \text { inhabitants) }\end{array}$ & $\begin{array}{l}\text { Own Cal- } \\
\text { culation }\end{array}$ \\
\hline 12 & $\begin{array}{l}\text { School enroll- } \\
\text { ment, tertiary }(\% \\
\text { gross) } \\
\text { SERT }_{\mathbf{i}, \mathbf{t}}\end{array}$ & $\begin{array}{l}\text { "Gross enrolment ratio is the ratio of total enrolment, regardless of age, } \\
\text { to the population of the age group that officially corresponds to the lev- } \\
\text { el of education shown. Tertiary education, whether or not to an ad- } \\
\text { vanced research qualification, normally requires, as a minimum condi- } \\
\text { tion of admission, the successful completion of education at the sec- } \\
\text { ondary level." }\end{array}$ & WDI 2011 \\
\hline 13 & $\begin{array}{l}\text { ICT goods im- } \\
\text { ports }(\% \text { total } \\
\text { goods imports) } \\
\text { ICTM }_{\mathbf{i}, \mathbf{t}}\end{array}$ & $\begin{array}{l}\text { Information and communication technology goods imports include tel- } \\
\text { ecommunications, audio and video, computer and related equipment; } \\
\text { electronic components; and other information and communication tech- } \\
\text { nology goods. Software is excluded. }\end{array}$ & WDI 2011 \\
\hline
\end{tabular}

In order to estimate the described scheme in panel data regressions, it is assumed that a higher level of initial per capita GDP reflects a greater stock of physical capital per capita following [5]. Following [24], it is also assumed that the initial stock of human capital is reflected in the lagged value of per capita output in the short-run. The Solow-Swan model predicts that, for given values of the control variables, an equi-proportionate increase in the initial levels of state variables reduces the growth rate. Thus we can write the model of output per capita growth rate for this panel dataset as:

$\left(y_{i, t}-y_{i, t-1}\right) / y_{i, t-1} \approx \alpha y_{i, t-1}+X_{i, t} \beta+v_{i}+\tau_{t}+\varepsilon_{i, t}$

Where, $\mathrm{y}_{\mathrm{i}, \mathrm{t}}$ is per capita gross domestic income (GDI) in sample country $i(i=1, \ldots$, 11) during the period ' $t$ ' $(t=2000, \ldots, 2010)$, $\mathrm{y}_{\mathrm{i}, \mathrm{t}-\mathrm{1}}$ is the initial per capita GDP in region ' $\boldsymbol{i}$ ' 
in period ' $\boldsymbol{t}-\mathbf{1}$ ', ' $\boldsymbol{\alpha}<\mathbf{0}$ ' reflecting the convergence speed, $X_{i, t}$, is a row vector of control variables in region ' $\boldsymbol{i}$ ' during period ' $\boldsymbol{t}$ ' with associated parameters ' $\beta$ ', ' $v_{\mathbf{i}}$ ' is a country specific effect and $\varepsilon_{i, t}$ is the error term. If we assume that:

$$
\left(\mathbf{y}_{\mathrm{i}, \mathrm{t}}-\mathrm{y}_{\mathrm{i}, \mathrm{t}-1}\right) / \mathbf{y}_{\mathrm{i}, \mathrm{t}-1} \approx \ln \left(\mathrm{y}_{\mathrm{i}, \mathrm{t}} / \mathrm{y}_{\mathrm{i}, \mathrm{t}-1}\right)
$$

we can approximate equation (1.3) as:

$\ln \left(y_{i, t} / y_{i, t-1}\right)=\alpha \ln \left(y_{i, t-1}\right)+\ln X_{i, t} \beta+v_{i}+\tau_{t}$

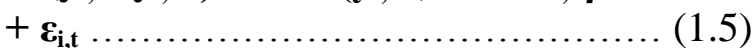

Moving $\ln \left(\mathrm{y}_{\mathrm{i}, \mathrm{t}}\right)$ from right-hand side to lefthand side, we obtain the dynamic panel data model:

$$
\ln y_{i, t}=(\alpha+1) \ln \left(y_{i, t-1}\right)+\ln X_{i, t} \beta+v_{i}+\tau_{t}+
$$

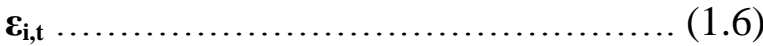

\section{Sampling and Estimation Techniques}

The dimensions of dataset are 24 countries (Bangladesh, Bru Nei Darul Islam, China, Indonesia, India, Iran, Israel, Jordan, Japan, Kazakstan, Kryzgystan, Cambodia, Korea, Kowait, Lao PDR, Malaysia, Oman, Pakistan, Philippines, Russia, Saudi Arabia, Thailand, Tajikstan and Yemen) and 11 years (2000-2010) which are mostly dictated by the availability of data. Collection of data is done from World Development Indicators (WDI) and International Telecommunication Union (ITU) for selected Asian countries.

Test for potential endogeneity and heteroskedasticity have been applied that reveal that endogeneity and heteroskedasticity both exist via statistical significance of test statistics. More specifically, existence of endogeneity calls for IV estimation and presence of heteroskedasticity necessitates GMM estimator.

Table 2. Durbin-Wu-Hausman Tests For Endogeneity In IV Estimation

Null Hypothesis $\left(\mathbf{H}_{\mathbf{0}}\right)$ : Regressor is Exogenous

\begin{tabular}{|c|c|c|c|}
\hline Test & Notation & Statistic & $\begin{array}{c}\text { p- } \\
\text { value }\end{array}$ \\
\hline Wu-Hausman F test & $F(1,206)$ & 42.049 & $\mathbf{0 . 0 0 0 0}$ \\
\hline $\begin{array}{c}\text { Durbin-Wu- } \\
\text { Hausman } \chi^{2} \text { test }\end{array}$ & $\chi^{2}(1)$ & 44.001 & $\mathbf{0 . 0 0 0 0}$ \\
\hline
\end{tabular}

Table 3. IV-Heteroskedasticity Tests Using

\begin{tabular}{|c|c|c|c|}
\hline \multicolumn{4}{|c|}{ Null Hypothesis $\left(\mathbf{H}_{\mathbf{0}}\right)$ : Disturbance is Homoskedastic } \\
\hline Test & $\chi^{2}(6)$ & \multicolumn{2}{|c|}{ p-values } \\
\hline \multicolumn{2}{|c|}{ Pagan-Hall General Test Statistic } & 11.542 & 0.1728 \\
\hline \multicolumn{2}{|c|}{$\begin{array}{c}\text { Pagan-Hall Test w/assumed Nor- } \\
\text { mality }\end{array}$} & 15.110 & $\mathbf{0 . 0 5 7 0}$ \\
\hline \multicolumn{2}{|c|}{ White/Koenker $n R_{c}^{2}$ Test Statistic } & 21.155 & 0.0067 \\
\hline \multicolumn{2}{|c|}{$\begin{array}{l}\text { Breusch-Pagan/Godfrey/Cook- } \\
\text { Weisberg }\end{array}$} & 30.214 & 0.0002 \\
\hline
\end{tabular}
Levels Of IVs

Panel data models with small samples produce biased coefficient estimates using ordinary least squares 'OLS', fixed effects ' $F E$ ' and random effects 'RE' [3]. Such bias is tackled with using estimators based on the General Method of Moments 'GMM', which are consistent for ' $n \rightarrow \infty$ ' with fixed ' $\boldsymbol{t}$ '. System Generalized Method of Moments 'SYS-GMM' is employed for the panel data analysis. GMM estimation technique is attributed to [2] which is ameliorated as 'SYSGMM' by [9]. SYS-GMM is a better estimation technique since i) differencing eliminates the unobservable country-specific effects; ii) instrumental-variable 'IV' approach deals with the endogeneity of explanatory variables; iii) $1^{\text {st }}$-differenced estimator is combined with the estimator in levels to form a more efficient 'system estimator'.

$$
Z_{i, t}=\beta X_{i, t}+v_{i}+\eta_{i, t} \quad i=1, \ldots, N ; t=1, \ldots, T
$$

Where $\mathbf{Z}$ is the given dependent variable, $\mathbf{X}$ is a row vector of control variables. $\boldsymbol{v}_{\mathbf{i}}$ represents the unobserved country level effect and $\boldsymbol{\eta}_{\mathbf{i}, \mathrm{t}}$ is the error term, assumption that $\boldsymbol{v}_{\mathbf{i}}$ and $\boldsymbol{\eta}_{\mathbf{i}, \mathbf{t}}$ are independent for each ' $\boldsymbol{i}$ ' over all ' $\boldsymbol{t}$ ' and there is no autocorrelation in $\boldsymbol{\eta}_{\mathrm{i}, \mathrm{t}}$. Using the methodology of SYS-GMM, this section estimates the effect of ICT on economic convergence across the sample countries.

[19] has suggested a method to inquire the existence of convergence using system GMM (SGMM). This assumption necessitates a steady state in the logic that deviations from long run values are not systematically associated to the fixed effects. Stating in terms of coefficients, convergence occurs if the coefficient of the lagged dependent variable in 
the model is less than 1 in absolute terms. [20] also suggests that if the coefficient of the lagged dependent variable exceeds 1, SGMM becomes void. For convergence process another condition is laid in [19] that "deviations from the steady state level must not be correlated with the fixed effects $\left(\hat{u}_{\mathrm{i}, \mathrm{t}}\right)$ "'. Such can be achieved by incorporating the initial condition of the dependent variable in the regression equation.

Post estimation tests include Hansen test of over-identifying restrictions that is a joint test of model specification and appropriateness of the instruments. SYS-GMM uses more instruments than DIFF-GMM causing the Sargan test to be weak. However, in this study, the Hansen (Robust Sargan) test is used which overcomes this weakness of Sargan test. Moreover, the rule of thumb that number of instruments $\leq$ number of countries is also considered for this statistical concern [18]. Hence our choice of SYS-GMM survives this statistical concern. This test statistics indicates that the model is well specified and the instrument vector is appropriate. Moreover, [2] test, applied to differenced residuals, for the first order AR(1) and second order AR(2) serial correlations are also estimable. AR(1) is expected to reject null hypothesis of no autocorrelation since both of the following difference equations have $\boldsymbol{\varepsilon}_{\mathbf{i}, \mathbf{t}-\mathbf{1}}$ :

$\Delta \varepsilon_{\mathrm{i}, \mathrm{t}}=\varepsilon_{\mathrm{i}, \mathrm{t}}-\varepsilon_{\mathrm{i}, \mathrm{t}-1}$
$\Delta \varepsilon_{\mathrm{i}, \mathrm{t}-1}=\varepsilon_{\mathrm{i}, \mathrm{t}-1}-\varepsilon_{\mathrm{i}, \mathrm{t}-2}$

Test for $\operatorname{AR}(2)$ is more important since it inquires the presence of autocorrelation in levels and should be insignificant.

Table 4. SYSTEM GMM Estimates (Role of Demographic Complementary Factors and ICT in Convergence)

\begin{tabular}{|c|c|c|c|c|}
\hline \multicolumn{5}{|c|}{ Dependent Variable: Gross National Income $\left(\mathbf{Y P C}_{\mathrm{i}, \mathrm{t}}\right)$} \\
\hline & Coefficients & Standard Errors & t-statistics & p-values \\
\hline $\mathbf{Y P C}_{\mathrm{i}, \mathrm{t}-1}$ & 0.9617 & 0.0487 & 19.75 & 0.000 \\
\hline ICTMI $_{\mathrm{i}, \mathrm{t}}$ & 0.0119 & 0.0052 & 2.29 & 0.023 \\
\hline ICTSERT $_{i, t}$ & 0.0028 & 0.0010 & 2.84 & 0.005 \\
\hline $\mathbf{P 1 5 6 4}_{\mathrm{i}, \mathrm{t}}$ & 0.1042 & 0.0731 & 1.43 & 0.156 \\
\hline URBNP $_{\mathrm{i}, \mathrm{t}}$ & $\mathbf{0 . 0 2 2 3}$ & 0.0063 & 3.51 & 0.001 \\
\hline TRD $_{\mathrm{i}, \mathrm{t}}$ & -0.0558 & 0.0301 & -1.85 & 0.065 \\
\hline ELTKW $_{i, t}$ & 1.2082 & 0.1600 & 7.55 & 0.000 \\
\hline $\mathbf{Y P C}_{\mathrm{i}, \mathrm{t}(0)}$ & -0.0584 & 0.0240 & -2.44 & 0.016 \\
\hline $\mathbf{C}$ & -0.1483 & 0.3543 & -0.42 & 0.676 \\
\hline \multicolumn{5}{|c|}{ Time Dummies } \\
\hline yrtd_02 & 0.0176 & 0.0167 & 1.06 & 0.291 \\
\hline yrtd_03 & 0.0246 & 0.0153 & 1.61 & 0.110 \\
\hline yrtd_04 & 0.0265 & 0.0133 & 2.00 & 0.047 \\
\hline yrtd_05 & 0.0213 & 0.0117 & 1.83 & 0.069 \\
\hline yrtd_06 & 0.0196 & 0.0111 & 1.77 & 0.079 \\
\hline yrtd_07 & 0.0200 & 0.0109 & 1.84 & 0.067 \\
\hline yrtd_08 & 0.0009 & 0.0114 & 0.08 & 0.939 \\
\hline yrtd_09 & -0.0297 & 0.0160 & -1.86 & 0.065 \\
\hline \multicolumn{5}{|c|}{ Other Tests and Statistics } \\
\hline Obs. $=216$ & Countries $=24$ & Instruments $=30$ & \multicolumn{2}{|c|}{$\mathbf{F}(\mathbf{1 5}, \mathbf{2 3})=7162[\mathbf{p}=0.000]$} \\
\hline \multicolumn{2}{|c|}{ p-value: Hansen J-Test $=0.222$} & \multicolumn{3}{|c|}{$\mathbf{M}_{1}: p=0.208 \& \mathbf{M}_{2}: p=0.301$} \\
\hline \multicolumn{5}{|c|}{ Difference in Hansen tests / C-tests: $[\mathrm{p}=0.244, \mathrm{p}=0.308, \mathrm{p}=0.137 \& \mathrm{p}=0.433]$} \\
\hline \multicolumn{5}{|c|}{ Source: Author's calculations using Stata (Special Edition) 12.0 user defined command xtabond2 } \\
\hline
\end{tabular}

Notes: Following [19], model is estimated by two steps SGMM with argument small.

In this estimation, ICT goods imports (\% total goods imports) ICTM $_{\mathrm{i}, \mathrm{t}}$ is used as in additional instrumental variable following [18]. It is selected as an additional since it is ex- pected to have no direct and significant relation with national income but is highly suspected to directly increase ICTMI. It is because in most of the sample countries, the 
ICTMI components (FBBS, FIS, FTL, INTU and MBLC) are not domestically produced rather imported. Therefore, use of ICTM as an additional instrument is justified. Conse-

\section{Explanatory Notes:}

i) The standard errors are given in parentheses. ii) t-statistics are based on standard errors. iii) Number of instruments < number of observations as advocated in [19] \& [20] \& p-value of Hansen J-Test is considerably higher than conventional levels of 0.05 and 0.01 as suggested in [20]. iv) Difference-inHansen tests or C-tests are applied to check the validity of subsets of instruments for:

i. the instruments of the level equations (exogenous variables \& time dummies excluded);

ii. exogenous variables \& the time dummies, and;

iii. moment conditions produced by the differences equations (exogenous variables \& time dummies excluded).

There is not enough evidence to reject the null hypotheses set in these four tests of difference-in-Hansen/C-tests.

\section{Interpretation}

The estimated coefficient on the lagged dependent variable is 0.9617 which is less than 1 , which means that the steady-state assumption holds. Moreover, the initial condition variable comes with a negative sign (-0.1483) and implies higher growth in response to lower starting YPC when other regressors are kept constant. Such concurs with the findings in [6] and [17].

Information and communication technology (ICTMI) is statistically significant and has a positive influence on YPC (national income) as depicted by its positive sign of regression coefficient $(0.119 \%$ increase in national income due to $10 \%$ increase in ICTMI). ICTSERT (ICT $\times$ SERT) is also used in the regression which captures the interaction of ICT and school enrollment rate at tertiary level. This coefficient is statistically significant and has positive influence on national income $(0.028 \%$ increase in national income due to $10 \%$ increase in ICTSERT). This im- quently, due to lack of association between YPC and ICTM and strong association between ICTM and ICTMI, ICTM is used as an 'external instrument' as suggested in [20]. plies that ICT has complementarily with tertiary level of education. In simpler terms, highly educated users (labor) of ICT are economically more productive labor. Similar results are also expected from ICTSERS (ICT $\times$ SERS) an interaction of ICT and school enrollment rate at secondary level. But due to relatively lower level of education, the influence on national income is likely to be lower. Moreover, a smaller portion of population having secondary education is likely to be ICT users, while a bigger portion of population having tertiary education is expected to be ICT users. Therefore, the proxy ICTSERS is not empirically tested in this research. [1] for some Asian countries, highlight the weaknesses of tertiary education system that is dominated by client-oriented private sector institutions.

The proxy for economically active youth, population aged between 15-64 years is also included. Though age group up to 64 years is not considered young, but lack of data on below 50 years of age of population is not available, so this proxy is dictated by data availability. The meaning of young population here is in terms of their contemporariness to ICT and physical and mental fitness to adopt and use ICT. It shows a positive relationship with national income $(0.1042 \%$ increase in national income due to $1 \%$ increase in p1564). It is justified since young labor force is more ICT-savvy. 'ICT-savvy' means proficient user of information and communication technology. ICT revolution is not more than two or three decades older, accordingly the younger population has undergone proper training of ICT under academic programs. United Nations (UN), World Summit on the Information Society (WSIS) and World Programme of Action for Youth (WPAY) also confirm the high potential of youth in learning the use and development of ICT applications.

Another segment of population that is hypothesized to be relatively more productive is 
the urban population. Population in urban areas gets better education and job opportunities due to urbanization economies. Urbanization economies contain benefits like proximity of markets, skilled and more educated labor, financial services, better information and communication facilities and knowledge spillovers. Considering these facts, this demo-tech income regression includes urban population (URBNP) along with ICT as demographic factor. This regressor is showing positive influence on national income and supporting the argument of urbanization economies $(0.223 \%$ increase in national income due to $10 \%$ increase in URBNP). It is statistical significant. In an economic jargon, this coefficient indicates towards 'ICTaugmented agglomeration economies' in large urban areas. This term is devised from the standard term of agglomeration economies.

Trade openness TRD turns out to be positive contributor to national income $(-0.558 \%$ increase in national income due to $10 \%$ decrease in TRD). Its negative role can be attributed unfavorable terms of trade for developing countries, majority of which can be seen in our sample.

Electricity consumption in this regression justifies its inclusion via positive sign of its coefficient and significance at $1 \%$. Moreover, in terms of magnitude, its coefficient is the highest $(1.2082 \%$ increase in national income due to $1 \%$ increase in ELTKW). Because the role of electricity consumption is not limited only to complementing the ICT. Rather electricity consumption complements other nonICT sectors as well and contributes to economic growth via other channels. The role of electricity for ICT is not only in complementary rather it serves as a pre-requisite for ICT to function. Consequently, it is safely stated that electricity consumption has strong complementarily with ICT.

Overall significance of the model is acceptable (at 1\%, 5\% and 10\% levels of significance) as revealed by F-test of joint significance. The condition that number of observations is greater than number of instruments holds in this case i.e. $(216>30)$. Hansen test of correct specification and over-identifying restrictions has a p-value of greater than 0.05 . i.e. $(p$-value $=0.222>0.05)$ implying that all over-identified instruments are exogenous. The Arellano \& Bond test for first order ' $\mathrm{M}_{1}$ ' and second order ' $\mathrm{M}_{2}$ ' correlation i.e. $\mathrm{AR}(1)$ and $\operatorname{AR}(2)$ show $p$-value of greater than 0.000 . i.e. $\left(\mathrm{M}_{1}\right)_{\mathrm{p} \text {-value }}=0.208>0.05$ and $\left(\mathrm{M}_{2}\right)_{\mathrm{p} \text {-value }}=0.301>0.05$. Hence there is no second order serial correlation in residuals.

C-test ([7]; [19]) for the validity of subsets of instruments for level and difference equations are also satisfactory. These tests are four in number and have same criteria, i.e. the p-value should be greater than 0.05 :

$(\mathbf{C} \text {-test })_{\text {Ho: GMM-differenced instruments are exogenous }}=$ $0.244>0.05$

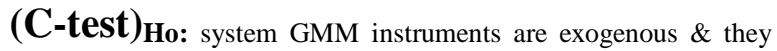
increase Hansen J-test $=0.308>0.05$

(C-test) Ho: GMM instruments excluding IV-instruments are exogenous $=0.137>0.05$

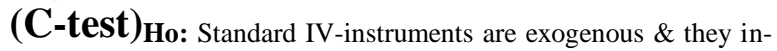
crease Hansen J-test $=0.433>0.05$

There is not enough evidence to reject the null hypotheses set in these four tests of difference-in-Hansen/C-tests.

\section{Conclusion}

Based on empirical results in this paper the role of ICT in achieving convergence which is found to be supportive. Though the magnitude of relationship is not large yet it is substantial form the point of view of UDCs. Since in UDCs ICT is adopted and not produced domestically, its contribution is expected to be low as compared to that in ICT producing countries (some DCs). The contribution is economically meaningful as well. The richest ICT related regional databases are found in case of OECD countries for instance 'ICT database and Eurostat'. In UDCs, access to ICT is also low as compared to that in that in DCs but an optimist fact is the presence of youth and other favorable demographic features. Some of the problems of scientific research in developing countries, such as creating an increased pool of trained people, providing more resources and strengthening the whole national infrastructure, can only be solved through time. Policy 
makers should focus more on designing the policy in considering ICT as a phenomenon, deeply embedded into every sector of the economy.

\section{Acknowledgements}

We want to cordially thank Prof. Dr. Zakir Hussain, Vice Chancellor, Government College University, Faisalabad, Pakistan for his thorough support.

\section{References}

[1] P. G. Altbach, Private higher education revolution: an introduction. In Philip G. Altbach \& Daniel C. Levy (Ed.), Private Higher Education: A Global Revolution. Rotterdam, the Netherlands: Sense Publishers, 2005, pp. 1-9.

[2] M. Arellano and S. Bond 1991, Some tests of specification for panel data: Monte Carlo evidence and an application to employment equations, Review of Economic Studies, vol. 58, 1991, pp. 277-97.

[3] B. H. Baltagi, Econometric analysis of panel data: econometric theory. $4^{\text {th }}$ Edition, John Wiley \& Sons, Ltd Wiley, 2008.

[4] R. J. Barro, and X. Sala-i-Martin, Convergence, Journal of Political Economy, vol. 100, issue 2, 1992, pp. 223-251.

[5] R. J. Barro and X. Sala-i-Martin, Economic growth. London: The MIT Press, 1995.

[6] R. J. Barro and X. Sala-i-Martin, Economic growth. London: The MIT Press, 2004.

[7] F. C. Baum, An introduction to modern econometrics using Stata, Texas: Stata Press, 2006.

[8] W. J. Baumol, Productivity growth, convergence, and welfare: What the longrun data show. American Economic Review, 76(5), 1986, pp. 1072-1085.

[9] R.W. Blundell and S. Bond, Initial conditions and moment restrictions in dynamic panel data models, Journal of Econometrics, 87, 1998, pp. 115-143.

[10] F. Bouvet, EMU and the dynamics of regional per capita income inequality in
Europe, Journal of Economic Inequality, vol. 8, issue 3, 2002, pp. 323-344.

[11] G. Cette and J. Lopez, What explains the ICT diffusion gap between the major industrialized countries: An empirical analysis? International Productivity Monitor, vol. 17, 2008, pp. 28-39.

[12] P. F. Drucker, The world according to Peter Drucker take-aways. Free Press, 1998.

[13] S. V. Dunaway and M. D. Kaufman and P. Swagel, Regional convergence and the role of federal transfers in Canada. IMF Working Papers 03/97, International Monetary Fund, 2003.

[14] G. D. Hutcheson, The economic implications of Moore's law. In H. R. Huff (Ed.), Into the Nano Era, 2009, pp. 1138. Berlin Heidelberg: Springer.

[15] ITU Measuring information society. Geneva: ITU, 2010. Available: http://www.itu.int/ITU/ict/publications/idi/material/2010/MIS 2010_without_annex_4-e.pdf

[16] S. Karagiannis, Knowledge-based economy, convergence and economic growth: evidence from the European Union. Journal of Economic Asymmetries, vol. 4, issue 2, 2007, pp. 65-85.

[17] N. G. Mankiw, D. Romer and D. N. Weil, A contribution to the empirics of economic growth. Quarterly Journal of Economics, vol. 107, issue 2, 1992, pp. 407-437.

[18] E. Mileva, Using Arellano-Bond dynamic panel GMM estimators in Stata. Economics Department, Fordham University, 2007, New York. Available: http://www.fordham.edu/ economics/mcleod/Elitz-UsingArellano\% E2\%80\%93Bond GMMEstimators.pdf

[19] D. Roodman, How to do xtabond2: An introduction to "Difference" and "System" GMM in Stata, Working Papers 103, 2006, Center for Global Development.

[20] D. Roodman, A note on the theme of too many instruments. Oxford Bulletin of Economics and Statistics, vol. 71, issue 1, 2009, pp. 135-158. 
[21] X. Sala-I-Martin, G. Doppelhofer and R. I. Miller, Determinants of long-term growth: a Bayesian averaging of classical estimates (BACE) Approach. American Economic Review, vol. 94, issue 4, 2004, pp. 813-835.

[22] R. M. Solow, A contribution to the theory of economic growth, Quarterly Journal of Economics, vol. 70, issue 1, 1956, pp. 65-94.
[23] R. M. Solow, We'd better watch out. New York Times Book Review, vol. 12, issue 7, April, 1987, p. 36. New York Review of Books. Available: http://www.standupeconomist.com/pdf/ misc/solow-computer-productivity.pdf

[24] M. Soto, Capital flows and growth in developing countries: recent empirical evidence, OECD Development Centre Technical Paper No.160, Paris, 2000.

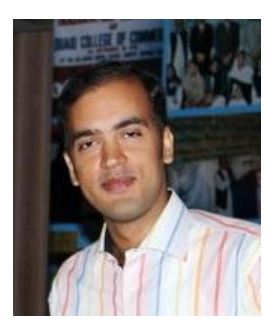

Bilal MEHMOOD has graduated the Master in Economics in 2003. He obtained an MPhil degree in 2006 in Economics from GC University, Lahore, Pakistan. He is currently completing his $\mathrm{PhD}$ degree from GC University, Faisalabad. He also holds Diploma in Information Technology from Punjab Information Technology Board, Pakistan. He is an awarded of The Gold Standard of International Award for Young People, The Duke of Edinburgh Award. He is a participant of International Growth Centre (IGC) Pakistan, a policy consortium set up by the London School of Economics (LSE) and Oxford University. Currently, he is serving GC University, Lahore, Pakistan as a senior lecturer in Department of Economics. He has conducted and edited Survey projects with Punjab Small Industries Corporation under Government of The Punjab, Pakistan. He is the author of more than 15 articles and a book the fields of ICT economics and knowledge economy, among others. His work is currently in Romanian Review of Social Sciences (RRSS) and is forthcoming in Oeconomics of Knowledge and Romanian Economic Journal (REJ). His work concentrates on the role of ICT and knowledge in development of UDCs.

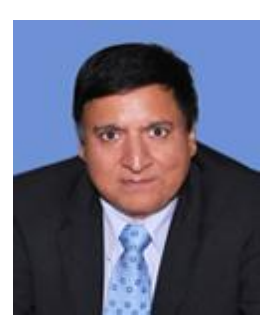

Parvez AZIM is Foreign Faculty Professor of Economics and a $\mathrm{PhD}$ in Economics from Texas A\&M University, USA. He is not only a known figure in the field of economics but also in the field of mathematical economics. His articles and books are well recognized in the comity of economic scientists. $\mathrm{He}$ is currently supervising $\mathrm{PhD}$ and MPhil theses. Previously he has served at Quaid-e-Azam University Islamabad, Govt. College University Lahore, University of Gujrat, University of Sargodha, in the Ministry of Education Brunei Dar-us-Salam and on number of national and international projects. He is a member of editorial board of International Journal of Pluralism and Economics Education USA. 